\title{
ANALISIS PENGEMBANGAN SEKTOR PARIWISATA KABUPATEN SUMBAWA
}

\author{
Ade Dewi Yulianti ${ }^{{ }^{*}}$, Aris Soelistiyo ${ }^{a}$, Setyo Wahyu Sulistyono

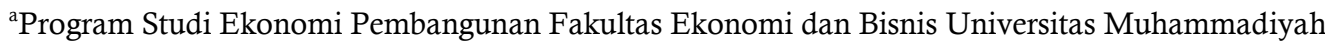 \\ Malang \\ *Corresponding author:: adedewiyulianti99@gmail.com
}

\begin{tabular}{l}
\hline Article Info \\
\hline Article history: \\
Received 14 April 2021 \\
Revised 07 May 2021 \\
Accepted 10 May 2021 \\
Available online 20 May \\
2021
\end{tabular}

\section{Keywords:}

Tourism, development, driving factors.

JEL Classification

\begin{abstract}
By utilizing exotic resources, making tourism places as known as the tourism sector in Sumbawa Regency that plays an important role in regional economic growth in Sumbawa Regency, not only playing a role in the economy but also the tourism sector as an additional source of income, both regional income and influential. on per capita income, this study aims to determine the strategy in seeking the development of the tourism sector of Sumbawa Regency, hotel tax, restaurant tax, entertainment tax, number of tourist visits, Micro, Small and Medium Enterprises (MSMEs) and Tourism Sector Manpower as independent variables. how is the development of Sumbawa district in the tourism sector, where the tourism sector is in the form of tourism sector income (the contribution of the tourism sector) as the dependent variable with the 2015-2019 research period. The research analysis uses panel data analysis with the Fixed-Effects (FE) approach. The estimation results show that hotel taxes, the number of tourist visits, MSMEs, and workers receive HO, which has increased and has a positive and significant influence on Sumbawa Regency in the sector. Tourism.
\end{abstract}

\section{PENDAHULUAN}

Pariwisata sektor dengan salah satu menyumbang devisa tertinggi di Indonesia, dimana pemerintah Indonesia sangat gencar dalam meningkatkan kualitas sektor pariwisita di era modern serta teknologi yang semakin maju saat ini. Namun meningkatkan kualitas objek wisata dalam bidang pariwisata dan memperkenalkan budaya serta pesona indonesia ke seluruh Negara yang menjadi value added bagi daerah maupun Indonesia untuk peningkatan kualitas ekonomi Indonesia tidak lepas dari peran pemerintah-pemerintah daerah yang ada di Indonesia di setiap daerah yang ikut serta medorong Indonesia untuk besaing di mancanegara. Salah satu daerah dengan keunggulan sektor pariwisatanya dengan pemanfaatan Sumber Daya Alam yaitu berada di Kabupaten Sumbawa.

Pemanfaatan Sumber Daya dalam bidang Pariwisata ini untuk mampu meningkatkan kesejahteraan masyarakat yang ada di Kabupaten Sumbawa, maka pembangunan destinasi Pariwisata salah satu upaya untuk mempercepat pertumbuhan ekonomi daerah yang ada di Kabupaten Sumbawa dengan memberikan pelayanan ruang public seperti rekreasi hiburan. Dimana dalam bidang pariwisata diharapkan mampu memberikan peluang lapangan kerja serta berusaha dalam sector pariwisata yang dimana berada pada sekitar tempat wisata seperti, perdagangan, angkutan, hiburan, 
jasa, telekomunikasi, infrastruktur (hotel,restoran, hiburan), bukan hanya itu dimana sebagai upaya menambah asset daerah yang nantinya akan menjadi investasi jangka panjang.

Kabupaten Sumbawa memiliki potensi yang begitu besar sebagai daerah tujuan destinasi wisata. Namun potensi ini akan bisa berkembang dan diketahui oleh publik jika semuanya mampu di kelolah dengan baik serta dipromosikan secara intensif. Kabupaten Sumbawa saat ini begitu sangat gencarnya melakukan pengembangan di bidang pariwisata, menginggat potensi yang dimilki begitu tinggi.Untuk itu perlu adanya pengembangan pariwisata agar daerah menjadi lebih optimal. Penetapan potensi destinasi pariwisata Sumbawa terbagi dari beberapa jenis daya tarik wisata yaitu wisata alam, wisata budaya dan wisata buatan dimana terdiri dari 127 destinasi wisata dari 24 kecamatan yang ada di Kabupaten Sumbawa.

\section{Grafik 1. Jumlah Kunjungan Wisatawan Kabupaten Sumbawa}

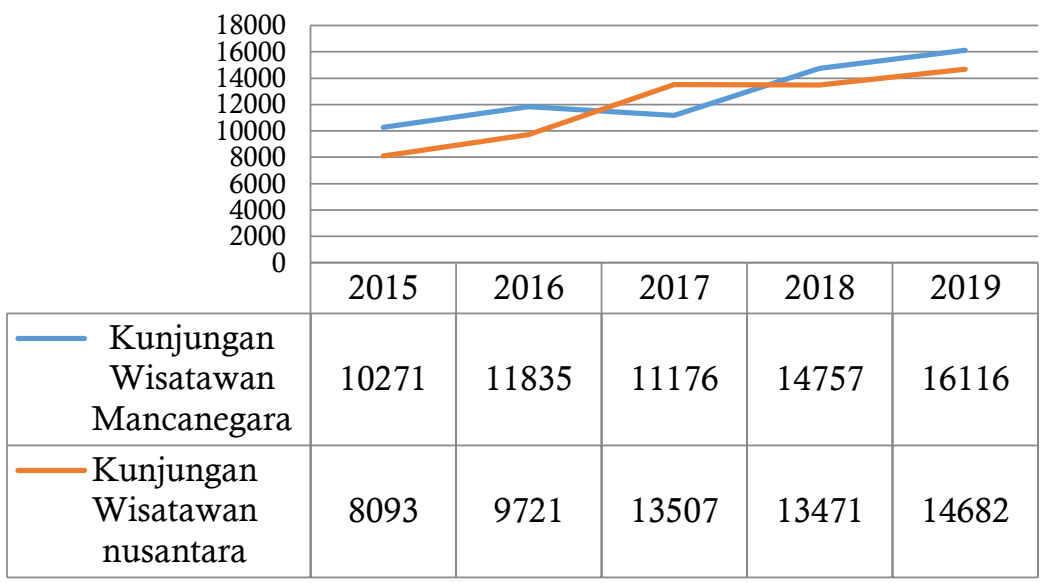

Sumber: (Dinas Pemuda Olahraga dan Pariwisata Kabupaten Sumbawa)

Dari data jumlah kunjungan wisatawan di Kabupaten Sumbawa dari tahun 2015-2019 menunjukan lebih di dominasi oleh wisatawan manjanegara dibandingkan dengan wistawan Nusantara. Meski Kabupaten Sumbawa saat ini belum begitu dikenal sebagai destinasi pariwisata unggul yang ada di Indonesia, buka berarti Sumbawa tidak mampu memiliki daya tarik wisata taraf internasional, namun sesungguhnya sumbawa adalah surga wisata yang masih tersembunyi, di kabupaten sumbawa bagian intisari dari surga wisata alam, syurga wisata budaya, syurga wisata kuliner dan syurga wisata minat khusus.

Dengan pemanfaatan sumber daya yang eksotis menjadikan tempat pariwisata sebagai mana yang telah diketahui sector pariwisata di Kabupaten Sumbawa bahwa sangat berperan penting dalam pertumbuhan ekonomi daerah Kabupaten Sumbawa, bukan hanya berperan dalam perkonomian namun sector pariwisata juga sebagai tambahan sumber penghasilan pendapatan, baik pendapatan daerah maupun berpengaruh pada pendapatan perkapita, dimana betujuan meratakan dalam upaya kesempatan kerja maupun pendapatan masyarakat yang berada di kabupaten Sumbawa, dimana pajak pada sector pariwisata merupakan salah satu sebagai acuan 
terpenting dalam Pendapatan Asli Daerah (PAD) yang berada di Kabupaten Sumbawa seperti Pajak Resoran,Pajak Hotel, Pajak Hiburan dan dapat mengarah atau berpengaruh pada UMKM, Ketenaga Kerjaan, dan Jumlah Kunjungan Wisatawan pada Sektor Pariwisata di Kabupaten Sumbawa Besar, sedangkan untuk sektor pariwisata, merupakan pendapatan dari sektor pariwisata berupa retrebusi daerah sektor pariwisata Kabupaten Sumbawa.

Maka berdasarkan fenomena yang telah dijabarkan tersebut, peneliti ingin melakukan penelitian dengan judul "Analisis pengembangan Sektor Pariwisata Kabupaten Sumbawa". Pada penelitian kali ini, fokus masalah yaitu kondisi pariwisata dan penalaran, factor penentu dalam pengembangan pariwisata. Sehingga analogi yang terbentuk mengarah pada suatu batasan masalahdalam penelitian ini ialah, mengenai sektor pariwisata, serta mengetahui subjek factor pendorong terhadap pengembangan sektor pariwisata Kabupaten Sumbawa dan keadaan sektor pariwisata pada Kabupaten Sumbawa, serta upaya dalam pengembangannya.

Didukung dengan penelitian terdahulu Penelitian terdahulu oleh, (Nurhayati, N., \& Suhendar, 2020) Dengan Analisis Optimalisasi Penerimaan Daerah Sektor Pariwisata Dalam Meningkatkan Pendapatan Asli Daerah Kab. Kuningan. Dimana dalam tujuan penelitian ini, Analisis Optimalisasi Penerimaan Daerah Sektor Pariwisata untuk Meningkatkan Pendapatan Asli Daerah (PAD) di Kabupaten Kuningan. Hasil penelitian ini, menunjukkan bahwa Pengaruh Jumlah pada Kunjungan Wisatawan Hotel, Jumlah Kunjungan Objek Wisata, dan Jumlah Kunjungan Wisatawan Restoran terhadap Pendapatan Asli Daerah (PAD) mengalami peningkatan pada setiap bulannya dan secara simultan. Sedangkan pada Jumlah Kunjungan Wisatawan Hotel meningkat maka pada penerimaan pajak hotel mengalami peningkatan pula sehingga berpengaruh terhadap Pendapatan Asli Daerah. Dan Jumlah Kunjungan Objek Wisata berpengaruh terhadap Pendapatan Asli Daerah, Jumlah Kunjungan Wisatawan Restoran mengalami peningkatan maka secara otomatis pun Pajak Restoran mengalami peningkatan, sehingga dapat meningkatkan Pendapatan Asli daerah, Penelitian terdahulu oleh, (Rahma \& Handayani, 2013) Dengan Pengaruh Jumlah Kunjungan Wisatawan, Jumlah Obyek Wisata Dan Pendapatan Perkapita Terhadap Penerimaan Sektor Pariwisata Di Kabupaten Kudus. Dimana dalam tujuan penelitian ini, menganalisis pengaruh variabel Jumlah Kedatangan Wisatawan, Daya Tarik Tousrist, dan Pendapatan Perkapita Sektor Pariwisata pada Pemerintah Kabupaten Kudus. Hasil penelitian ini, menunjukkan bahwa Secara parsial variabel jumlah wisatawan, variabel jumlah daya tarik pariwisata, dan variabel pendapatan perkapita berpengaruh signifikan. Dan dari ketiga variabel yang paling dominan pengaruhnya terhadap penerimaan sektor pariwisata di Kabupaten Kudus adalah variabel jumlah pariwisata Penelitian terdahulu oleh (Arraniry, 2018) Dengan Analisis Pengaruh Sektor Pariwisata Terhadap Pendapatan Asli Daerah di Provinsi Nusa Tenggara Barat (Tahun 2012-2016). Dimana dalam tujuan penelitian ini, untuk menganalisis pengaruh jumlah wisatawan, jumlah hotel, panjang jalan, serta produk domestik regional bruto terhadap 
pendapatan asli daerah melalui sektor pariwisata di Provinsi Nusa Tenggara Barat. Penelitian ini menggunakan data sekunder yang didapat melalui Kantor Badan Pusat Statistik Provinsi Nusa Tenggara Barat. Hasil penelitian ini, menunjukkan bahwa bahwa dari tahun 2012-2016, jumlah hotel dan produk domestik regional bruto berpengaruh positif dan signifikan terhadap pendapatan asli daerah. Sedangkan jumlah wisatawan berpengaruh negatif dan panjang jalan berpengaruh positif tetapi tidak signifikan terdapat pendapatan asli daerah.

Sehingga tujuan pada penelitian ini Untuk mengetahui factor penentu yang menjadi pengaruh pengembangan pada pariwisata di Kabupaten Sumbawa. Untuk mengetahui strategi dalam upaya pengembangan sektor pariwisata Kabupaten Sumbawa.

\section{METODEPENELITIAN}

Pada penelitian ini yaitu data sekunder selama lima Tahun terhitung pada tahun 2015-2019 melalui metode dokumentasi berupa data yang menjadi factor- factor pendorong dalam mengupayakan pengembangan kabupaten sumbawa pada sektor pariwisata yaitu jumlah pajak hotel, jumlah kunjungan wisatawan, jumlah pajak retouran, jumlah pajak hiburan, jumlah tenaga kerja, jumlah usaha mikro kecil menengah (UMKM) dan sektor pariwisata pada lima tahun tehitung pada tahun 2015-2019. Alat analisis data yang digunakan peneliti dalam melakukan penelitian sesuai dengan rumusan masalah, tujuan yang telah di jabarkan maka alat analisis yang digunakan yaitu, mengunakan analisis regresi Data Panel, Selain itu data yang dipergunakan yaitu data dalam kurun waktu (time series) terhitung pada tahun 2015 sampai dengan tahun 2019. dan pada deret lintang (cross section) data yang diambil yaitu dimana kabupaten Sumbawa terdiri dari 24 kecamatan, maka dalam penelitian ini hanya mengambil 12 wilayah kecamatan yang ada di Sumbawa, yang dimana di lihat dari nilai tertinggi yang terdapat pada variabel terikat yaitu dari jumlah pendapatan daerah perkecamatan di kabupaten Sumbawa yang terdiri 24 kecamatan yang ada di kabupaten Sumbawa dan terdiri dari 60 observasi.

Yit $=b 0+\mathrm{X} 1+\mathrm{X} 2+\mathrm{X} 3+\mathrm{e}$.

Yit : Penerimaan Sektor Pariwisata perkecamatan (dalam rupiah)

$\mathrm{X}_{1} \quad$ : Pajak Hotel perkecamatan (dalam rupiah)

$\mathrm{X}_{2} \quad$ : Pajak Restoran perkecamatan (dalam rupiah)

$\mathrm{X}_{3} \quad$ : Pajak Hiburan perkecamatan (dalam rupiah)

$\mathrm{X}_{4} \quad$ : Jumlah Kunjungan Wisatawan perkecamatan (dalam orang)

$\mathrm{X}_{5} \quad$ : UMKM perkecamatan (dalam usaha)

$\mathrm{X}_{6} \quad$ : tenaga kerja pariwisata perkecamatan (dalam rupiah)

$\mathrm{b}_{0} \quad$ : intersep/ Konstanta

b1 : koefisien regresi Pajak Hotel perkecamatan

$b_{2} \quad$ : koefisien regresi Pajak Restoran perkecamatan

b3 : koefisien regresi Pajak Hiburan perkecamatan

$\mathrm{b}_{4} \quad$ : koefisien regresi Jumlah Kunjungan Wisatawan perkecamatan

$b_{5} \quad$ : koefisien regresi UMKM perkecamatan 
b5 : koefisien regresi enaga kerja pariwisata perkecamatan

e : Disturbance Error (Variabel Penganggu)

\section{HASIL DAN PEMBAHASAN}

Pada serangkaian pengelolahan data panel yang telah di uji maka, Berdasarkan hasil uji chow yang dipilih untuk mengestimasi data panel adalah model Fixed- Effects (FE), pada hasil uji Hausman yang dipilih untuk mengestimasi data panel adalah model Fixed- Effects (FE), oleh karna itu untuk menentukan uji hipotesis dan determinasi yang digunakan model yang tebaik pada sektor pariwisata Kabupaten Sumbawa yaitu pada model FixedEffects (FE), Dimana pada model intercept yang tidak sama pada setiap subjek (cross section), namun pada slop pada setiap subjek tidak berubah seiring waktu.

Tabel 2. Fixed- Effects (Fe).

\begin{tabular}{ccccc}
\hline Variable & Coefficient & Std. Error & t-Statistic & Prob. \\
\hline C & 6199393. & 1613301. & 3.842676 & 0.0004 \\
PHOT & 1.211042 & 0.317065 & 3.819536 & 0.0004 \\
PRES & 0.432061 & 0.227677 & 1.897691 & 0.0646 \\
PHIB & -0.885789 & 0.461432 & -1.919652 & 0.0617 \\
KUWIS & 787.7302 & 319.5664 & 2.464997 & 0.0179 \\
UMKM & 131527.0 & 48354.84 & 2.720038 & 0.0095 \\
TK & 3172.778 & 3771.174 & 0.841324 & 0.4049 \\
\multicolumn{5}{c}{ Effects Specification } \\
Cross-section fixed (dummy variables) \\
R-squared & 0.991533 & Mean dependent var & 22732026 \\
Adjusted R-squared & 0.988106 & S.D. dependent var & 7772407. \\
F-statistic & 289.3304 & Durbin-Watson stat & 2.231937 \\
Prob(F-statistic) & 0.000000 & & \\
\hline
\end{tabular}

1) Uji Hipotesis

a) Uji T ( Uji Persial)

Hipotesis X1(Pajak Hotel)

$\mathrm{H}_{0}$ :Besarnya pajak hotel tidak mepengaruhi Sektor Pariwisata Kabupaten Sumbawa

$\mathrm{H}_{1}$ :Besarnya pajak hotel mepengaruhi Sektor Pariwisata Kabupaten Sumbawa

Hipotesis X2 (Pajak Restauran)

$\mathrm{H}_{0}$ :Besarnya pajak restauran tidak mepengaruhi pendapatan Sektor Pariwisata Kabupaten Sumbawa

$\mathrm{H}_{1}$ :Besarnya pajak restauran mepengaruhi pendapatan Sektor Pariwisata Kabupaten Sumbawa

Hipotesis X3 (Pajak Hiburan)

$\mathrm{H}_{0}$ :Besarnya pajak Hiburan tidak mepengaruhi Sektor Pariwisata Kabupaten Sumbawa

$\mathrm{H}_{1}$ :Besarnya pajak Hiburan mepengaruhi sektor pariwisata Kabupaten Sumbawa 


\section{Hipotesis X4 ( $\Sigma$ Kunjungan Wistawan) \\ $\mathrm{H}_{0}$ :Besarnya $\Sigma$ kunjungan wistawan tidak mepengaruhi sektor pariwisata Kabupaten Sumbawa \\ $\mathrm{H}_{1}$ :Besarnya $\Sigma$ kunjungan wistawan Sektor Pariwisata Kabupaten Sumbawa \\ Hipotesis X1( $\Sigma$ UMKM) \\ $\mathrm{H}_{0}$ :Besarnya $\Sigma$ UMKM tidak mepengaruhi Sektor Pariwisata Kabupaten Sumbawa \\ $\mathrm{H}_{1}$ :Besarnya $\Sigma$ UMKM mepengaruhi Sektor Pariwisata Kabupaten Sumbawa \\ Hipotesis X1( $\Sigma$ Tenaga Kerja) \\ $\mathrm{H}_{0}$ :Besarnya $\Sigma$ Tenaga Kerja mepengaruhi Sektor Pariwisata Kabupaten Sumbawa \\ $\mathrm{H}_{1}$ :Besarnya $\Sigma$ Tenaga Kerja mepengaruhi Sektor Pariwisata Kabupaten Sumbawa}

2) Kriteria Penguji

$\mathrm{H}_{0}$ ditolak jika probabilitas t lebih kecil dari 0.05

Berdasarkan output nilai probabilitas t-statistik untuk variabel X1(pajak hotel), sebesar 0.0004, nilai tersebut lebih kecil dari 0.05, sehingga di

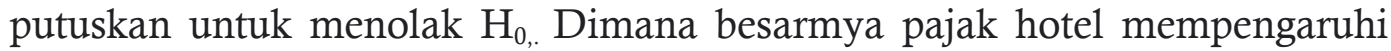
sektor pariwisata Kabupaten Sumbawa.

Berdasarkan output nilai probabilitas t-statistik untuk variabel X2 (pajak Restouran), sebesar 0.0646, nilai tersebut lebih besar dari 0.05,

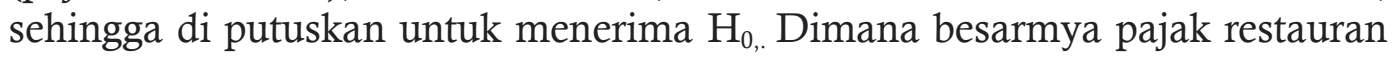
tidak mempengaruhi sektor pariwisata Kabupaten Sumbawa.

Berdasarkan output nilai probabilitas t-statistik untuk variabel X3 (pajak hiburan), sebesar 0.0617, nilai tersebut lebih besar dari 0.05, sehingga di putuskan untuk menerima $\mathrm{H}_{0}$, Dimana besarmya pajak hiburan tidak dapat mempengaruhi sektor pariwisata Kabupaten Sumbawa.

Berdasarkan output nilai probabilitas t-statistik untuk variabel X4 (jumlah kunjungan wisatawan), sebesar 0.0179, nilai tersebut lebih kecil dari 0.05 , sehingga di putuskan untuk menolak $\mathrm{H}_{0}$. Dimana besarmya jumlah kunjungan wisatawan dapat mempengaruhi sektor pariwisata Kabupaten Sumbawa.

Berdasarkan output nilai probabilitas t-statistik untuk variabel X5 (UMKM), sebesar 0.0095, nilai tersebut lebih kecil dari 0.05, sehingga di putuskan untuk menolak $\mathrm{H}_{0}$. Dimana besarmya UMKM dapat mempengaruhi sektor pariwisata Kabupaten Sumbawa.

Berdasarkan output nilai probabilitas t-statistik untuk variabel X6 ( $\Sigma$ Tenaga Kerja), sebesar 0.4049 , nilai tersebut lebih kecil dari 0.05 , sehingga di putuskan untuk menerima $\mathrm{H}_{0}$. Dimana besarnya Tenaga Kerja tidak dapat mempengaruhi sektor pariwisat Kabupaten Sumbawa

3) Uji F ( simultan)

a) Hipotesis X1(Pajak Hotel)

$\mathrm{H}_{0}$ : besarnya pajak hotel, pajak restauran,pajak hiburan, 
jumlah kunjungan wisatawan, jumlah UMKM, jumlah dan Tenaga Kerja tidak mepengaruhi sektor pariwisata Kabupaten Sumbawa

$\mathrm{H}_{1}$ : besarnya pajak hotel, pajak restauran,pajak hiburan , jumlah kunjungan wisatawan, jumlah UMKM, dan jumlah Tenaga Kerja mempengaruhi sektor pariwisata Kabupaten Sumbawa

b) Kriteria Penguji

$\mathrm{H}_{0}$ di tolak jika probabilitas $\mathrm{F}$ lebih kecil dari 0.05

Berdasarkan hasil output di atas, didapatkan nilai prob (F-statistik) sebesar 0.000000 nilai tersebut lebih kecil dari 0.05 , sehingga di putuskan untuk menolak $\mathrm{H}_{0, \text {. }}$ Dimana besarnya pajak hotel, pajak restauran, pajak hiburan, jumlah kunjungan wisatawan, jumlah UMKM, dan jumlah Tenaga Kerja. Mempengaruhi sektor pariwisata Kabupaten Sumbawa.

4) Koefesien Determinasi $\left(\mathrm{R}^{2}\right)$

Berdasarkan output diatas, didapatkan nilai R-squared sebesar 0.991533. Sedangkan nilai Adjust R- Square 0.988106, dimana nilai R- square adalah berkisaran antara 0 sampai dengan 1 . Hasil R- square yang mendekati 0 berarti variabel independen (bebas) memiliki kekuatan yang lemah dalam menjelaskan variabel dependen (terikat). Sedangkan R- square yang mendekati 1 bebrarti variabel independenya (bebas) dapat dikatan kuat dalam menjelaskan variabel dependen (terikat).

Sehingga Nilai R- Square 0.991533 menunjukan bahwa variabel terikat dependen $(Y)$ yaitu pendapatan asli daerah dimana dapat dijelaskan pada variabel bebas independen $(\mathrm{X})$, yang terdiri dari pajak hotel (X1), pajak restauran (X2), pajak hiburan (X3), jumlah kunjungan wisatawan (X4), jumlah UMKM (X5) dan jumlah Tenaga kerja (X6) sebesar $99.15 \%$. Sedangkan sisanya $0.85 \%$ lainnya di pengaruhi oleh factor diluar model, atau dijelaskan dalam variabel lain yang tidak terdapat dalam model.

Dari nilai $99.15 \%$ dapat dijelaskan pada keenam variable bebas tersebut memiliki pengaruh yang besar pada pendapatan asli daerah selama priode pengamatan yaitu tahun 2015-2019. Sedangkan sisanya sebesar 0.85 $\%$ menunjukan factor lain yang belum ada dalam penelitian ini maupun mempengaruhi fluktuasi sektor pariwisata Kabupaten Sumbawa. Sehingga penelitian ini, factor -faktor yang belum terdapat pada penelitian ini, yang dimana berupa investasi, infrastruktur, dan lain-lainnya yang mempengaruhi sektor pariwisata Kabupaten Sumbawa.

5) Pembahasan Hasil Analisis Data secara persial

a. Pengaruh Pajak Hotel, Terhadap Sektor Pariwisata.

Uji signifikasi, yaitu uji t (persial), pada variabel bebas yaitu pajak hotel (X1) memperoleh nilai coefficient sebesar 0.1211042 , nilai $t$ statistic sebesar 3.819536 dan nilai probability sebesar 0.0004, maka pada variabel bebas X1 yaitu berpengaruh positif dan signifikan terhadap variabel Terikat yaitu sektor pariwisata $(\mathrm{Y})$.

Hasil penelitian ini sejalan dengan penelitian terdahulu 
oleh, (Nurhayati, 2020). dimana semakin banyaknya hotel yang terdapat pada kabupaten sumbawa, maka akan semakin besar pula pajak yang diterima pada sektor pariwisata, kemudian semakin banyak wisatawan yang berkunjung pada suatu daerah, dimana perlu diimbangi dengan infrastruktur yang memadai, salah satunya jumlah hotel yang semakin meningkat. Pendapatan asi daerah pada pada pajak hotel tertinggi terdapat pada kecamatan Labuan Badas, Moyo Utara dan Kabupaten Sumbawa. Dimana kecamatan tersebut merupakan kecamatan yang sering dikunjungi dalam melakukan penginapan.dan kecamatan yang strategis, serta dekat dengan penduduk setempat.

b. Pengaruh Pajak Restouran, Terhadap Sektor Pariwisata.

Uji signifikasi, yaitu uji t (persial ), pada variabel bebas yaitu pajak retauran (X2) memperoleh nilai coefficient sebesar 0.432061 , nilai t statistic sebesar 1.897691 dan nilai probability sebesar 0.0646 , maka pada variabel bebas X2 yaitu berpengaruh positif dan tidak signifikan terhadap variabel Terikat yaitu sektor pariwisata meskipun tidak berpengaruh signifikan angka probabilitity pada pajak restoran hampir mendekati signifikan sehingga bisa dikatan memiliki pengaruh, namun pengaruh pajak restoran pada sektor pariwisata hanya berpengaruh sedikit.

Hasil penelitian ini secara teori.Tidak Mendukung hipotesis yang diajukan yang menyatakan bahwa Pajak restouran tidak berpengaruh signifikan terhadap sektor pariwisata. Hal ini di pengaruhi oleh jumlah kunjungan wisatawan di Kabupaten Sumbawa baik secara kenyamanan serta cita rasa dan harga pada setiap Restouran yang ada di kabupaten sumbawa dapat mempengaruhi jumlah pajak restouran yang ada di kabupaten sumbawa. Sehingga mampu meningkatkan penerimaan sektor pariwisata pada pajak restouran.Kecamatan yang sering di kunjungi baik wisatawan nusantara maupun mancanegara yaitu terletak pada Kecamatan Kabupaten Sumbawa dan Labuan Badas, yang merupakan tempat yang lokasinya berdampingan dengan wilayah administrasi Kabupaten Sumbawa.

c. Pengaruh Pajak Hiburan, Terhadap Sektor Pariwisata.

Uji signifikasi, yaitu uji t (persial), pada variabel bebas yaitu pajak hiburan (X3) memperoleh nilai coefficient sebesar -0.885789 , nilai t statistic sebesar -1.919652 dan nilai probability sebesar 0.0617, maka pada variabel bebas X3 yaitu berpengaruh negatif dan tidak signifikan terhadap variabel Terikat yaitu sektor pariwisata (Y).

Hasil penelitian ini secara teori.Tidak Mendukung hipotesis yang diajukan yang menyatakan bahwa Pajak Hiburan tidak berpengaruh signifikan terhadap sektor pariwisata. Hal ini di pengaruhi oleh jumlah kunjungan wisatawan di Kabupaten Sumbawa baik secara daya tarik yang kuraang memiliki ciri khas, serta penyelenggaran event atau festival khas daerah, dan hiburan 
dapat mempengaruhi jumlah penerimaan pajak restauran yang ada di kabupaten sumbawa. Sehingga perlunya pemerintah dalam mengadakan event atau festival secara kreatif lagi yang dapat mendatangkan wisatawan untuk berkunjung sehingga penerimaan yang diterima pada pajak hiburan terhadap sektor pariwisata dapat secara optimal dan berpengaruh dalam meningkatkan perekonomian daerah Kabupaten Sumbawa salah satunya pada sektor pariwisata. Kecamatan yang sering dikunjungi dengan penerimaan pajak yang tertinggi serta wilayah yang strategis yait terletak pada kecamatan Labuhan Badas Kecamatan Sumbawa dan Kecamatan Unter Iwes.

d. Pengaruh Jumlah Kunjungan Wisatawan Terhadap Sektor Pariwisata.

Uji signifikasi, yaitu uji t (persial), pada variabel bebas yaitu Jumlah Kunjungan Wisatawa (X4) memperoleh nilai coefficient sebesar 787.7302, nilai t statistic sebesar 2.464997 dan nilai probability sebesar 0.0179 , maka pada variabel bebas X4 yaitu berpengaruh positif dan signifikan terhadap variabel Terikat yaitusektor pariwisata (Y).

Hasil penelitian ini sejalan dengan penelitian yang dilakukan oleh (Arraniry, 2018),(Nurhayati, 2020), (Rahma, 2013), menunjukan bahwa jumlah wisatawan berpengaruh positif terhadap Sektor Pariwiwsata, dan hasil penelitian ini di dukung oleh teori (Austriana, 2005) hal ini dapat dilihat dari data jumlah kunjungan wisatawan setiap tahunnya terhitung pada masa penelitian 2015-2019 mengalami signifikan. Secara teori sejalan dimana semakin banyak jumlah wisatawan yang berkunjung ke Kabupaten Sumbawa, maka akan semakin meningkat penerimaan sektor pariwisata.

e. Pengaruh UMKM Terhadap Sektor Pariwisata.

Uji signifikasi, yaitu uji t (persial), pada variabel bebas yaitu UMKM (X5) memperoleh nilai coefficient sebesar 131527.0, nilai t statistic sebesar 2.720038 dan nilai probability sebesar 0.0095 , maka pada variabel bebas X5 yaitu berpengaruh positif dan signifikan terhadap variabel Terikat yaitu sektor pariwisata (Y).

Hasil penelitian ini secara teori yaitu (Ardiwidjaja, 2020.), mendukung hipotesis yang dilakukan yang dimana UMKM memiliki dampak positif serta berpengaruh signifikan terhadap Kabupaten Sumbawa, sehingga secara tidak langsung dapat membantu pendapatan perkapita yang ada di Kabupaten Sumbawa.

f. Pengaruh Tenaga Kerja Terhadap Sektor Pariwisata.

Uji signifikasi, yaitu uji t (persial ), pada variabel bebas yaitu Tenaga Kerja (X6) memperoleh nilai coefficient sebesar 3172.778, nilai t statistic sebesar 0.841324 dan nilai probability sebesar 0,4049 maka pada variabel bebas X5 yaitu berpengaruh positif dan tidak signifikan terhadap variabel Terikat yaitu sektor pariwisata (Y). 
Hasil penelitian ini secara teori Mendukung hipotesis yang diajukan (Keynes, 1924), (suparmoko, 2000), dan (Nuh, 1996) yang menyatakan bahwa tenaga kerja tidak berpengaruh signifikan terhadap sektor pariwisata. Hal ini dipengaruhi oleh secara tidak langsung maupun langsung yang berdapak pada sektor pariwisata dalam bidang ketenaga kerjaan yang dimiliki sektor pariwisata di Kabupaten Sumbawa yaitu yang disebabkan lapangan pekerjaan yang minim serta upah yang minim pada sektor pariwisata. Sehingga mampu mengurangi tingkat kemiskinan dan pengangguran pada sektor pariwisata.

2. Strategi dalam Mengupayakan Pengembangan Sektor Pariwisata Kabupaten Sumbawa.

Banyaknya Potensi Sektor Pariwisata Kabupaten Sumbawa, tentunya pemerintah berupaya dalam melaksanakan pengembangan pariwisata yang tentunya akan berdampak baik serta profit bagi masyarakat asli daerah Kabupaten Sumbawa maupun pemerintah daerah kabupaten sumbawa (pendapatan perkapita, pendapatan asli daerah, pendapatan kontribusi) daerah Kabupaten sumbawa. Pengembagan pariwisata yang diupayakan pada dinas pariwisata Kabupaten Sumbawa saat ini yaitu sebagai berikut:

a. Zona wisata alam di Kawasan tiung sabangka (air terjun) yang belokasi di kecamatan alas, pantai (emang lestari, pandan sari, sampar goal) yang berlokasi di kecamatan lunyuk, pulau temudung dan pulau kaung berada di kecamatan alas dan kecamatan buer.

b. Zona wisata wahana hiburan putri balqis berada di Kecamatan Alas barat, saliper ate yang berada berlokasi di Kecamatan Sumbawa. Serta benungan mama ( waduk ) yang berada di lokasi Kecamatan Lape

c. Zona wisata belanja, yang dimana berada di desa tepal (pusat berbelanjaan) Berlokasi di Kecamatan Batu Lanteh, Desa Poto (pusat berbelanjaan) yang berlokasi di kecamatan Moyo Hilir. Serta Samawa baeng (pusat berbelanjaan), terletak di Kecamatan Sumbawa.

Pemerintah Kabupaten Sumbawa melalui dinas Pariwisata, yang dimana disaping mengelolah lahan, pemerintah juga mengupayakan tempat bagi masyarakat daerah Kabupaten Sumbawa yang tinggal pada sekeliling objek wisata untu membangun usaha dengan memanfaatkan potensi yang berada di Kabupaten Sumbawa. Dengan memperhitungkan serta menjaga kelestarian serta kebersihan objek wisata.

Pemerintah saat ini berfokus pada pengembangan dengan kawasan jasa industri pariwisata seperti hotel, restouran, hiburan, pusat berbelanja. Dimana hal tersebut sebagai penopang utama dalam meningkatkan pendapatan daerah maupun pendapatan Kontribusi dari sektor pariwisata, Kabupaten Sumbawa berupa Akomodasi hotel, rumah makan atau restouran, tempat hiburan serta pedangangan produk. Dimana para wisatawan yang berkunjung 
khususnya luar daerah memerlukan penginapan, makan minum, hiburan, dimana jika pengujung meningkat tentunya hotel, makan minum, hiburan dan lainya mendapatkan pendapatan, sehingga pajak pun akan ikut meningkat. Yang dimana memiliki peran yang cukup signifikan terhadap perekonomian daerah terutama PAD Kabupaten Sumbawa.

Pembangunan pada Sektor Pariwisata adalah bagian dari upaya-upaya dalam mengembangkan dan mengelolah objek destinasi wisata yang telah ada pada suatu daerah agar lebih baik lagi, karna pada setiap daerah tentunya memiliki keberagaman budaya, tradisi,dan seni serta kekayaan alam yang berlimpah, dan peninggalan-peninggalan purbakala yang berbeda-beda pada setiap daerahnya.

Menurut (Yoeti, 1985) pengembangan merupakan usaha dalam meningkatkan dan mengembangkan sesuatu yang telah ada. Pengembangan sektor pariwisata pada daerah tujuan wisata selalu akan diperhitungkan dengan keuntungan serta manfaat pada masyarakat sekelilingnya. Pada pengembangan pariwisata harus sesuai pada perencaaan serta program yang benar-benar matang, sehingga pemanfaatanya berdampak baik pada masyarakat, bidang social budaya, maupun pada bidang ekonomi.

Maka dalam melaksanakan peran dan Fungsinya pada pengembangan pariwisata di Kabupaten Sumbawa.Maka pemerintah harus melaksanakan upaya dalam pengembangan sarana dan prasarana pada sektor pariwisata. Sarana pariwisata terdapat pada tiga bagian yang terpenting yaitu:

a. Sarana utama Sektor Pariwisata (The main Stucture of Tourism) yaitu : hotel, restouran, hiburan, dalam hal ini hotel cukup banyak tersebar pada Kabupaten Sumbawa, dan pada restouran perlu dikembangankan lagi dalam infrasturktur serta yang menjadi ciri khas daerah dalam menarik wisatawan untuk berkunjung di Kabupaten Sumbawa. Serta Hiburan dengan ivent-iven tradisi daerah, serta infarstruktur yang mendukung.

b. Sarana Pelengkap Sektor Pariwisata (Complementary The Tourism Sector) yaitu: wisata budaya serta wisata Buatan dan Alam. Dimana pada Kabupaten Sumbawa pastinya memiliki wisata budaya yaitu peninggalan-peninggalan pubakala (musium) serta tradisi-tradisi yang kental akan tradisi-tradisi nenek moyang daerah Kabupaten Sumbawa. Pada wisata buatan yaitu dengan perkampungan tradisional, serta wahana-wahana pendukung, serta wisata alam berupa pantai, perbukitan, pegunungan dan pulau, dan air terjun yang telah memadai, namun butuh di kelolah secara efektif lagi dalam meningkatkan pendapatan kontribusi daerah Kabupaten Sumbawa.

c. Sarana Pendukung Sektor Pariwisata (Supporting The Tourism Sector) yaitu: pasar seni, kuliner, pusat peroleh-olehan, kerajinan daerah (UMKM produk khas daerah Kabupaten Sumbawa).

Pada pengembangan sektor pariwisata perlu diperhatikanya hal-hal yang berpengaruh dalam pelaksaannya. Didukung pada teori (Yoeti, 1985), terhadap prasarana kepariwisataan yaitu semua fasilitas yang memungkinkan pada sarana kepariwisataan dapat hidup dan berkembang, karnanya sehingga dapat memberikan pelayanan dalam memuaskan keperluan serta kebutuhan 
wisatawan yang beranekaragam. Prasarana tersebut yaitu

a. System Pelayanan wisatawan ( pusat informasi, kantor tour gayt atau pemadu wisata)

b. System telekomunikasi (jaringan, telepon, televsi,kantor post, radio dll)

c. System perhubungan (jalan raya atau jalan penghubung objek wisata, laut(pelabuhan), terminal, bandara, dan alat transportasi ( bus, pesawat, kapal, bouts )

d. System Pelayanan kesehatan (rumah sakit, puskesmas, klinik)

e. Pom bensin

f. Penyedian Listrik dan air bersih

g. System keamanan, penjaga wahana/ objek wisata, satpam, polisi. Satpol PP, dan pemadam kebakaran.

h. dan lain-lain.

Pada prasarana yang tertera diatas secara keseluruhan belum dimiliki sepenuhnya oleh kabupaten Sumbawa, baik dari segi telekomunikasi yaitu jaringan yang memadai, system perhubungan, jalan raya menuju objek wisata yang kurang memadai, pelabuhan yang minim, Kabupaten Sumbawa Hanya memiliki Bandara 1 saja yang terletak di wilayah Administrasi Kabupaten Sumbawa yaitu berada pada Kecamatan Sumbawa bandara tersebut bernama Sultan Muhammad Kaharuddin III Airport. System pelayanan kesehatan yang dapat terhitung begitu minim seperti puskesmas. System keamanan yang minim serta penyedian listrik dan air bersih yang kurang memadai yang berada di kawasan objek-objek wisata di Kabupaten Sumbawa.

Kabupaten Sumbawa tentunya memiliki sarana dan prasarana yang kurang memadai serta minim dengan keterbatasan baik dari pendapatan oleh pemerintah daerah Kabupaten Sumbawaa yang di dapatkan dengan pegeluaran yang di keluarkan oleh pemerintah Kabupaten Sumbawa dalam sektor pariwisata.Meskipun Kabupaten Sumbawa memiliki keterbatasan yang kurang memadai. Kabupaten Sumbawa juga tentu nya kaya akan keberagaman serta potensi Alam yang cukup baik, apabila semua itu di kembangkan dengan semaksimal mungkin.

Kekayaan potensi pariwisata pada Kabupaten Sumbawa dapat dilihat pada jenis-jenis objek wisata (air terjun, pulau, pegunungan serta wahanawahana pendukung lainnya, benda-benda peninggalan nenek moyang, museum hutan, dll.) kemudian Kabupaten Sumbawa juga memiliki Pusat serta cabang cindra mata atau pusat berbelanjaan khas daerah Kabupaten Sumbawa dengan kreativitas masyarakat Kabupaten Sumbawa (UMKM).

Peningkatan pada jasa usaha Pariwisata di Kabupaten Sumbawa adalah penopang utama bagi kontribusi sektor pariwisata untuk pendapatan asli daerah (PAD) Kabupaten Sumbawa yang berasal dari pajak Hotel, pajak Restoran, pajak Hiburan. Hal tersebut disebabkan oleh bertambahnya kunjungan wisatawan pada setiap tahunnya. wisatawan pada luar daerah tentunya membutuhkan jasa-jasa tersebut dalam menunjang kegiatan pariwista. Dapat dilihat pada tabel 4.pada pendapatan sektor pariwisata Kabupaten Sumbawa

Tabel 3. Perkembangan Sektor Pariwisata. 


\begin{tabular}{cccc}
\hline Tahun & Pendapatan Sektor pariwisata & Perkembangan & Persentase \\
\hline 2015 & $292,336,429$ & - & - \\
2016 & $299,827,742$ & $7,491,313$ & $2 \%$ \\
2017 & $312,262,650$ & $12,434,908$ & $4 \%$ \\
2018 & $337,496,972$ & $25,234,322$ & $8 \%$ \\
2019 & $396,137,932$ & $31,640,960$ & $17 \%$ \\
\hline
\end{tabular}

Berdasarkan tabel diatas pendapatan sektor pariwisata pada tahun 20152019 mengalami peningkatan yang cukup signifikan pada setiap tahunnya. Pada tahun 2016 sebesar 299,827,742 dengan besar perkembangan 2\% dari tahun sebelumnya.Pada tahun 2017 meningkat sebesar 312,262,650 dan perkembangannya sebesar 4\%. Kemudian pada tahun 2018 kembali meningkat sebesar 337,496,972 dengan perkembangan yaitu sebesar $8 \%$ dan pada tahun 2019 mengalami peningkatan sebesar 396,137,932 dengan perkembangan $17 \%$.

Bedasarkan uraian diatas, dapat disimpultkan bahwa adanya objek wisata yang dikelolah oleh pemerintah atau dinas pariwisata serta dikelolah secara pribadi sehingga dari keduanya yang membantu terhadap peningkatan pendapatan sektor pariwisata Kabupaten Sumbawa. Pada peningkatan pendapatan sektor pariwisata Kabupaten Sumbawa Tetap didukung Oleh PAD.

\section{KESIMPULAN}

Berdasarkan hasil pembahasan data, maka pada pajak hotel memiliki pengaruh yang positif dan signifikan terhadap sektor pariwisata Kabupaten Sumbawa yang disebabkan banyaknya jumlah kunjungan wisata yang menginap. Berdasarkan pajak restorant memiliki pengaruh positif namun tidak signifikan yang disebabkan oleh minimnya pengunjung, yang bisa berpengaruh dari lokasi yang kurang startegis, cita rasa, serta suasana pada restaurant, berdasarkan pajak hiburan memiliki pengaruh negatif dan tidak signifikan yang disebkan minimnya pengadaan ivent atau festival, tempat hiburan dll, pada jumlah kunjungan wisatawan dan umkm memiliki pengaruh positif dan signifikan hal tersebut merupakan hal yang mendukung dalam meningkatkan pendapatan perkapita masyarakat kabupaten sumbawa. Namun pada tenaga kerja memiliki pengaruh yang positif namun tidak signifikan yang dimana yang disebakan lapangan tenaga kerja serta krativitas masyarakat yang masih minim.

Perkembangan sektor pariwisata di Kabupaten Sumbawa yaitu pada hasil analisis data dan pembahasan yang telah dijabarkan yaitu pada bab empat hingga dapat ditarik kesimpulan yaitu Upaya terhadap pengembangan sektor pariwisata yang dapat dilakukan oleh lembaga atau Dinas Pariwisata Kabupaten Sumbawa dapat dikatakan Tidak semua dapat dikelolah dengan tercapai secara maksimal meliputi pada segi sarana dan prasarana, maupun objek wisata secara keseluruhan. Namun Kabupaten Sumbawa tetap mengalami peningkatan karna pendapatan sektor pariwisata yang didukung oleh pendapatan asli daerah, berupa pajak hotel, pajak restouran, pajak hiburan dan kontribusi yang termasuk dalam jasa pariwisata UMKM dan 
ketenagakerjaan yang merupakan salah satu fokus dalam upaya pengembangan yang sedang dilakukan oleh Dinas Pariwisata Kabupaten Sumbawa dalam meningkatakan kesejahteraan Kabupaten Sumbawa pada sektor pariwisata.

\section{DAFTAR PUSTAKA}

Ardika, I. W. (2007). Pusaka Budaya dan Pariwisata (P. Larasan).

Arraniry, F. (2018). Analisis Pengaruh Sektor Pariwisata Terhadap Pendapatan Asli Daerah di Provinsi Nusa Tenggara Barat (Tahun 20122016).

Boediono. (2010). Ekonomi Mikro (BPFE-UGM (Ed.); Edisi kedua).

Dinas Pemuda Olahraga dan Pariwisata Kabupaten Sumbawa, data diolah.

Gujarati, D. (2014). (2014). Basic Econometrics (McGraw-Hill (Ed.)).

Nurhayati, N., \& Suhendar, D. A. (2020). Analisis Optimalisasi Penerimaan Daerah Sektor Pariwisata Dalam Meningkatkan Pendapatan Asli Daerah Kab. Kuningan. 6, 1-17.

Piore dan Sabel, P. (1984). The Secend Industrial Divide: Possibilities For Prosperity (B. Book).

Pitana, I gde, \& Gayatri, P. G. (2005). Sosiologi Pariwisata (Andi).

Rahma, F. N., \& Handayani, H. R. (2013). Obyek Wisata Dan Pendapatan Perkapita Terhadap Penerimaan Sektor Pariwisata Di Kabupaten Kudus. Http://Ejournal-S1.Undip.Ac.Id/Index.Php/Jme, 2(2), 1-9. https://www.neliti.com/id/publications/19638/pengaruh-jumlahkunjungan-wisatawan-jumlah-obyek-wisata-dan-pendapatan-perkapita

Soekadijo, R. G. (2000). Anatomi Pariwisata (PT Gramedi).

Spillane, J. (2011). Ekonomi Pariwisata (Kanisius).

Unesco. (2009). Intangible Cultural Heritage.

Wibowo, H. D. (2009). Aspek Hukum Dan Kelembagaan dalam Peningkatan Efisiensi dan Efektivitas Pengelolahan Wilayah Pesisir. Jurnal Hukum.

Yoeti, O. A. (1985). Pemasaran Pariwisata : Tourism Maarketing (Angkasa (Ed.)). 